\title{
PENGARUH PEMBERIAN AIR REBUSAN DAUN JAMBU BIJI (PSIDIUM GUAJAVA) TERHADAP KADAR GLUKOSA DARAH DIABETES MELLITUS TIPE I PADA HEWAN MENCIT (MUS MUSCULUS) (Effect Of Guava's Boiled Water (Psidium Guajava) On Blood Glucose Levels Of Diabetes Mellitus Type I In Mice (Mus Musculus))
}

\author{
Taufan Citra Darmawan* \\ ${ }^{1}$ Prodi D3 Keperawatan Stikes William Booth Jl.Cimanuk No. 20 Surabaya. \\ Email: tp4n_thefujin@yahoo.com
}

\begin{abstract}
ABSTRAK
Pendahuluan: Diabetes Melitus (DM) adalah salah satu jenis penyakit degenerative yang mengalami peningkatan setiap tahun di negara-negara seluruh dunia. Di Indonesia fenomena diabetes melitus terkini tidak hanya menyerang lansia tapi juga rentang usia lainnya. Salah satu solusi alternatif yang dapat dicoba yaitu pengobatan tradisional dengan daun jambu biji. Penelitian sebelumnya terkait daun jambu biji mengatakan bahwa dalam daun jambu biji terdapat zat yang berdampak menurukan gula darah. Penelitian ini bertujuan untuk mengetahui secara langsung pengaruh rebusan daun jambu biji terhadap kadar glukosa darah. Metode: penelitian ini adalah true experiment Desain penelitian yang digunakan yakni pre post test control group design. Lokasi penelitian dilakukan di laboratorium biokimia Fakultas Kedokteran Universitas Airlangga Surabaya. Populasi dalam penelitian ini adalah hewan mencit sebanyak 32 ekor yang dibagi menjadi 2 kelompok perlakuan dan kontrol. Hasil dan Analisa: Dengan menggunakan uji chi square didapatkan hasil yang signifikan $\rho<\alpha=0,00<0,05$ yang artinya terdapat pengaruh pada rebusan air daun jambu biji terhapat penurunan glukosa darah pada mencit. Hasil penelitian 16 ekor mencit yang dilakukan uji coba didapatkan bahwa seluruh mencit mengalami penurunan kadar glukosa darah. Kesimpulan: air rebusan daun jambu biji (psidium guajava) dapat menurunkan kadar gula darah pada mencit jenis (mus muculus). Penelitian ini masih merupakan penelitian tahap awal dimana perlu dilakukan uji coba lebih lanjut terhadap spesimen hewan mamalia jenis lainnya sebelum dilakukan kepada manusia.
\end{abstract}

Kata kunci: Daun Jambu Biji, Diabetes Melitus, Glukosa Darah

\section{ABSTRACT}

Introduction: Diabetes Mellitus (DM) is a degenerative disease that is increasing every year in countries around the world. In Indonesia, the latest diabetes mellitus phenomenon not only affects the elderly but also other age ranges. One alternative solution that can be tried is traditional medicine with guava leaves. Previous research related to guava leaves said that in guava leaves there are substances that have an impact on lowering blood sugar. This study aims to determine directly the effect of guava leaf decoction on blood glucose levels. Method: This research is true experiment. The research design used is pre post test control group design. The research location was conducted in the biochemical laboratory of the Faculty of Medicine, Airlangga University, Surabaya. The population in this study were 32 mice which were divided into 2 treatment and control groups. Results and Analysis: Using the chi-square test, significant results were obtained $\rho<\alpha=0.00<0.05$, which means that there was an effect on boiling guava leaf water on a decrease in blood glucose in mice. The results of the study of 16 mice which were tested showed that all 
mice had decreased blood glucose levels. Conclusion: guava leaf (psidium guajava) boiled water can reduce blood sugar levels in mice (mus muculus). This research is still an early stage research where further trials are needed on specimens of other types of mammals before being carried out on humans.

\section{Keywords: Guava Leaves, Diabetes Mellitus, Blood Glucose.}

\section{PENDAHULUAN}

Diabetes Melitus (DM) adalah salah satu jenis penyakit degenerative yang mengalami peningkatan setiap tahun di negara-negara seluruh dunia Indonesia merupakan negara menempati urutan ke 7 dengan penderita DM sejumlah 8,5 juta penderita setelah Cina, India dan Amerika Serikat, Brazil, Rusia, Mexico. Angka kejadian DM menurut data Riskesdas 2013 terjadi peningkatan dari 1,1 $\%$ di tahun 2007 meningkat menjadi $2,1 \%$ di tahun 2013 dari keseluruhan penduduk sebanyak 250 juta jiwa (Depkes, 2013). Fenomena diabetes, terutama diabetes mellitus tidak hanya dialami oleh orang dewasa dan manula, namun juga remaja dan bahkan anak - anak yang mengalami diabetes mellitus rata - rata telah mengalami obesitas terlebih dahulu. Meski hanya factor genetik lebih menjadi faktor yang paling utama, pola makan dan pola hidup yang tidak sehat berperan sebagai penyumbang terbesar di masyarakat. Dari data terkini di dapatkan, usia penderita diabetes kini semakin muda, 1 dari 5 pederita diabetes masih berumur dibawah 40 tahun dengan jumlah sebanyak 1.671.000 orang. Sedangkan sisanya berusia 40 hingga 59 tahun dengan jumlah 4.651 .000 orang. Kelompok terakhir berusia 60-79 tahun berjumlah 2 jutaan orang (Fitri, 2015). Data statistik jumlah penderita diabetes di dunia versi WHO pada tahun 2012 dan proyeksi jumlah penderita diabetes dunia pada tahun 2030. Indonesia menduduki tempat ke 4 terbesar dengan pertumbuhan sebesar $152 \%$ atau dari 8.426 .000 orang pada tahun 2012 menjadi 21.257 .000 orang di tahun 2030 (Infodatin, 2015). Salah satu pilar utama pengelolaan diabetes adalah perencanaan makan, lebih dari $50 \%$ pasien tidak melaksanakannya. Selain itu latihan jasmani yang teratur memegang peran penting terutama pada DM tipe-1. Jika pasien telah melaksanakan program makan dan latihan jasmani teratur, namun pengendalian kadar glukosa darah belum tercapai, perlu ditambahkan obat hipoglikemik baik oral maupun insulin (Waspadji, 2013). Berdasarkan penelitian sebelumnya, pemberian perasan air buah jambu biji 0,517 $\mathrm{g} /$ hari dapat menurunkan kadar glukosa darah mulai minggu ketiga pada tikus yang diinduksi STZ (Yusof, 2014). Berdasarkan studi literature dari tanaman obat disebutkan bahwa infusa dan dekokta dari buah jambu biji dapat menurunkan kadar glukosa darah, serta pemberian ekstrak air buah jambu biji mempunyai efek menurunkan kadar glukosa darah yang sebanding dengan glibenklamid dosis 0,23 mg/kg BB (Sutrisna, 2015). Dari hal tersebut maka perlu dilakukan pengkajian yang mendalam untuk mengetahui efektivitas secara langsung terhadap kadar glukosa darah terutama dengan metode yang lebih steril dan aman untuk konsumsi.

\section{METODE PENELITIAN}

Rancangan penelitian ini tergolong jenis penelitian true experiment. Desain penelitian yang digunakan yakni pre post test control group design. Dalam penelitian ini ada kelompok intervensi dan kelompok kontrolnya sudah dirandomisasi. Lokasi penelitian dilakukan dilaboratorium biokimia 
Fakultas Kedokteran Universitas Airlangga Surabaya pada bulan juni tahun 2019. Populasi dalam penelitian ini adalah hewan percobaan yang akan dipakai dalam penelitian ini yaitu hewan mencit ( Mus Musculus) yang berjumlah 32 ekor. Sampel yang digunakan adalah hewan mencit (Mus musculus) dengan kondisi sehat fisik sehat dengan berat badan 20 - 30 gram dan usia 2-3 bulan. Kelompok pertama ( kontrol) yang terdiri dari 16 ekor hewan mencit yang tidak diberikan air rebusan daun jambu biji (psidium guajava) tetapi diinduksi STZ (streptozotocin) 60 $\mathrm{mg} / \mathrm{kg}$ BB. Kelompok kedua (perlakuan) diberikan air rebusan daun jambu biji (psidium guajava) dan diinduksi STZ (streptozotocin) $60 \mathrm{mg} / \mathrm{kg}$ BB. Percobaan pemberian rebusan air daun jambu biji dilakukan sampai 7 hari. Pengukuran kadar glukosa darah dilakukan dengan cara mengambil darah mencit melalui ekor yang dibersihkan menggunakan alcohol terlebih dahulu.

\section{HASIL PENELITIAN \\ Data Umum}

Didalam data umum di uraikan, umur, dan berat badan mencit dan jenisnya.

Tabel 1. Distribusi Frekuensi hewan percobaan berdasarkan umur tikus di di Laboratorium Biokimia Fakultas Kedokteran Universitas Airlangga Surabaya

\begin{tabular}{lllll}
\hline No & Umur & Frekuensi & $\begin{array}{l}\text { Presentase } \\
(\%)\end{array}$ \\
\cline { 3 - 4 } & & Perlakuan & Kontrol & \\
1 & 2 Bulan & 2 & 1 & $9,3 \%$ \\
2 & 3 Bulan & 14 & 15 & $90,7 \%$ \\
\hline & Total & 32 & & $100 \%$ \\
\hline
\end{tabular}

Tabel 2. Distribusi frekuensi sampel berdasarkan berat badan tikus di di Laboratorium Biokimia Fakultas Kedokteran Universitas Airlangga Surabaya

\begin{tabular}{|c|c|c|c|c|}
\hline \multirow[t]{2}{*}{ No } & \multirow{2}{*}{$\begin{array}{l}\text { Berat } \\
\text { Badan }\end{array}$} & \multicolumn{2}{|l|}{ Frekuensi } & \multirow{2}{*}{$\begin{array}{l}\text { Presentase } \\
(\%)\end{array}$} \\
\hline & & Perlakuan & Kontrol & \\
\hline 1 & $20-23$ & 14 & 11 & $50 \%$ \\
\hline \multirow[t]{2}{*}{2} & $24-27$ & 2 & 5 & $50 \%$ \\
\hline & Total & & & $100 \%$ \\
\hline
\end{tabular}

Berdasarkan data diatas didapatkan bahwa berat badan kontrol $(50 \%)$ dan perlakuan (50 \%) sama berat badan sampel adalah 20 23 gram dan $24-27$ gram .

Tabel 3. Distribusi frekuensi sampel berdasarkan jenis kelamin tikus di di Laboratorium Biokimia Fakultas Kedokteran Universitas Airlangga Surabaya

\begin{tabular}{lllll}
\hline No & $\begin{array}{l}\text { Jenis } \\
\text { Kelamin }\end{array}$ & Frekuensi & \multicolumn{2}{c}{$\begin{array}{l}\text { Presentase } \\
(\%)\end{array}$} \\
\cline { 3 - 4 } & & Perlakuan & Kontrol & \\
1 & Jantan & 16 & 16 & $100 \%$ \\
2 & Betina & 0 & 0 & $0 \%$ \\
& Total & 32 & & $100 \%$ \\
\hline
\end{tabular}

Berdasarkan data diatas didapatkan bahwa paling banyak adalah jenis kelamin jantan sejumlah 32 ekor (100\%).

\section{Data Khusus}

Kadar Glukosa darah hewan mencit sebelum dapat perlakuan

Tabel 4. Rata - rata Glukosa darah pada hewan mencit pada kelompok kontrol dan perlakuan sebelum diberikan air rebusan

Berdasarkan data diatas didapatkan bahwa umur daun jambu biji dan sebelum diberi STZ hewan mencit masing - masing yang umur 2 bulan (streptozotocin).

berjumlah 3 ekor $(9,3 \%)$ dan 3 bulan berjumlah 29

ekor $(90,7 \%)$. 


\begin{tabular}{|c|c|c|}
\hline No & $\begin{array}{l}\text { Kontrol } \\
\text { (mg/dl) }\end{array}$ & $\begin{array}{l}\text { Perlakuan } \\
(\mathrm{mg} / \mathrm{dl})\end{array}$ \\
\hline 1 & 118 & 107 \\
\hline 2 & 135 & 128 \\
\hline 3 & 126 & 125 \\
\hline 4 & 126 & 133 \\
\hline 5 & 138 & 129 \\
\hline 6 & 122 & 122 \\
\hline 7 & 130 & 129 \\
\hline 8 & 130 & 128 \\
\hline 9 & 115 & 135 \\
\hline 10 & 122 & 120 \\
\hline 11 & 127 & 130 \\
\hline 12 & 127 & 120 \\
\hline 13 & 130 & 117 \\
\hline 14 & 116 & 125 \\
\hline 15 & 130 & 118 \\
\hline 16 & 116 & 135 \\
\hline $\begin{array}{l}\text { Mean } \\
(\mathrm{mg} / \mathrm{dl})\end{array}$ & $126 \mathrm{mg} / \mathrm{dl}$ & $125 \mathrm{mg} / \mathrm{dl}$ \\
\hline
\end{tabular}

Berdasarkan data diatas didapatkan bahwa kadar glukosa darah masing - masing mean adalah kelompok control dan perlakuan dilakuan adaptasi masiing masing kelompok sesuai hasil adaptasi.

Tabel 5. Rata - rata Glukosa darah pada hewan mencit pada kelompok kontrol dan perlakuan setelah dalam kondisi DM.

\begin{tabular}{|c|c|c|}
\hline No & Kontrol (mg/dl) & $\begin{array}{l}\text { Perlakuan } \\
\text { (mg/dl) }\end{array}$ \\
\hline 1 & 416 & 291 \\
\hline 2 & 200 & 233 \\
\hline 3 & 235 & 269 \\
\hline 4 & 237 & 281 \\
\hline 5 & 200 & 241 \\
\hline 6 & 322 & 252 \\
\hline 7 & 385 & 241 \\
\hline 8 & 331 & 259 \\
\hline 9 & 331 & 252 \\
\hline 10 & 271 & 200 \\
\hline 11 & 408 & 231 \\
\hline 12 & 300 & 532 \\
\hline 13 & 421 & 261 \\
\hline 14 & 254 & 274 \\
\hline 15 & 300 & 292 \\
\hline 16 & 241 & 282 \\
\hline $\begin{array}{l}\text { Mean } \\
(\mathrm{mg} / \mathrm{dl})\end{array}$ & $303,25 \mathrm{mg} / \mathrm{dl}$ & $274,38 \mathrm{mg} / \mathrm{dl}$ \\
\hline
\end{tabular}

Berdasarkan data diatas didapatkan bahwa kadar glukosa darah setelah dikondisikan DM masing - masing mean adalah kelompok control dan perlakuan dilakukkan induksi STZ.

Tabel 6. Rata - rata Glukosa darah pada hewan mencit pada kelompok kontrol dan perlakuan setelah dalam kondisi DM dan diberi rebusan daun jambu.

\begin{tabular}{lll}
\hline No & Kontrol (mg/dl) & $\begin{array}{l}\text { Perlakuan } \\
(\mathbf{m g} / \mathbf{d l})\end{array}$ \\
\hline 1 & 416 & 110 \\
2 & 200 & 113 \\
3 & 235 & 81 \\
4 & 235 & 94 \\
5 & 200 & 121 \\
6 & 200 & 128 \\
\hline
\end{tabular}




\begin{tabular}{lll}
\hline 7 & 300 & 107 \\
8 & 383 & 110 \\
9 & 330 & 120 \\
10 & 270 & 130 \\
11 & 407 & 116 \\
12 & 300 & 126 \\
13 & 420 & 101 \\
14 & 253 & 108 \\
15 & 300 & 128 \\
16 & 241 & 107 \\
\hline $\begin{array}{l}\text { Mean } \\
(\mathrm{mg} / \mathrm{dl})\end{array}$ & $293,25 \mathrm{mg} / \mathrm{dl}$ & $113 \mathrm{mg} / \mathrm{dl}$ \\
\hline
\end{tabular}

hasil dengan uji chi- square hasil yang signifikan $\rho<\alpha=0,00<0,05$ dengan hasil Ho diterima dan $\mathrm{H} 1$ di tolak yang artinya terdapat pengaruh pada rebusan air daun jambu biji terhapat penurunan glukosa darah pada mencit.

\section{PEMBAHASAN}

Hasil penelitian terhadap hewan mencit dengan kondisi diabetes mellitus sebelum diberikan terapi air rebusan daun jambu biji

Berdasarkan data diatas didapatkan bahwa kadar glukosa darah setelah dikondisikan DM dan diberikan rebusan daun jambu biji masing masing mean adalah kelompok control kondisi DM tetap tinggi sedangkkan pada kelompok perlakuan kondsi DM mengalami penurunan selama 7 hari.

Tabel 7. Distribusi pemberian air rebusan daun jambu biji terhadap penurunan kadar glukosa darah pada mencit.

\begin{tabular}{lllll}
\hline No & Kelompok & Kriteria & Nilai \\
\cline { 3 - 5 } & & Menurun & $\begin{array}{l}\text { Tidak } \\
\text { menurun }\end{array}$ \\
& & \multicolumn{4}{c}{} \\
1 & Perlakuan & 16 & 0 & \\
2 & Kontrol & 7 & 9 & $\mathrm{P}=0,000$ \\
\hline & Total & 32 & & \\
\hline
\end{tabular}

Berdasarkan hasil data diatas menunjukkan bahwa pemberian air rebusan daun jambu biji terhadap penurunan kadar glukosa darah pada mencit pada yang mengalami penurunan dilakukan pada kelompok perlakuan sebanyak 16 ekor mencit $(100 \%)$ mengalami penurunan.

Jadi kesimpulan yang diperoleh dari table diatas dengan perhitungan SPSS.16 dengan tingkat signifikan $\alpha=<0,05$, dan di dapatkan
(Psidium guajava) pada hewan kontrol dengan rata - rata gula darah (303,25 mg/dl) dari sebanyak 16 ekor hewan mencit. Dan pada hewan perlakuan dengan rata- rata gula darah $(274,37 \mathrm{mg} / \mathrm{dl})$ dari sebanyak 16 ekor pada hewan mencit.

Hasil penelitian tersebut menunjukkan kelompok intervensi dan kontrol mengalami hiperglikemia. Hiperglikemia merupakan kondisi kadar glukosa dalam darah diatas normal, yaitu untuk glukosa plasma sewaktu > 200 $\mathrm{mg} / \mathrm{dl}$, glukosa plasma puasa > $140 \mathrm{mg} / \mathrm{dl}$.

Setelah dilakukan eksperimen dan observasi, hasil penelitian menunjukkan bahwa pada hewan mencit percobaan kelompok perlakuan dalam kriteria proses rata rata glukosa darah setelah dalam kondisi DM pada kelompok kontrol sebanyak 16 ekor dengan rata - rata $(293,25 \mathrm{mg} / \mathrm{dl})$ dan kelompok perlakuan sebanyak 16 ekor dengan rata - rata $(113 \mathrm{mg} / \mathrm{dl})$.

Menurut teori J. Milliton dalam jurnal Nur 2015, menjelaskan mengapa pada hewan percobaan tikus putih pada kelompok perlakuan mendapat hasil lebih banyak dalam 
proses penyembuhannya, hal ini dikarenakan pada hewan uji coba yang diperlakukan dalam proses pengobatan dan perawatan dilakukan secara teratur dan berkelanjutan dalam pemantauan.

Kecepatan dar proses penurunan glukosa darah dapat dipengaruhi dikarenakan mempunyai ke zat - zat yang terdapat dalam obat yang di berikan, jika obat tersebut mempunyai kemampuan untuk meningkatkan penurunan glukosa darah dengan cara merangsang lebih cara merangsang lebih cepat pertumbuhan sel - sel baru pada organ yang rusak (Prasetyo, 2012).

Menurut penelitian yang dilakukan oleh Agustiningsih dan Achmad pada tahun 2012 ditemukan kandungan flavonoid dalam daun jambu biji yaitu sebesar 4,6 mg/dl ekstrak. Dilihat dari jenis kandungan yang sama yang ada pada tanaman lain dan bereaksi sebagai antioksidan dalam mengatasi diabetes mellitus yaitu flavonoid dalam daun sirih merah baru memberikan efek hipoglikemik setelah pemberian ekstrak $20 \mathrm{mg}$ / kilogram berat badan penderita (wijoyo, 2012).

Kandungan tannin dalam daun jambu biji juga bekerja sebagai penenang sehingga dapat membantu menurunkan hormon stress pada hewan uji coba. Sesuai dengan teori menurut Nurrahmani (2012) dan Wijoyo (2010) mengatakan ada beberapa faktor yang dapat mempengaruhi kadar glukosa darah diantaranya kurang sensitifnya jaringan tubuh terhadap insulin karena jumlah atau aktivitas reseptor insulin berkurang pada sel, pola makan yang berlebihan menyebabkan kadar glukosa dalam darah meningkat karena keterbatasan sel $\beta$ pancreas untuk mensekresi insulin, obesitas mengakibatkan lemak yang berlebihan hal ini akan menyebabkan resistensi terhadap insulin, faktor genetik dapat menyebabakan diabetes mellitus karena diwarisinya gen penyebab diabetes mellitus, bahanbahan kimia dan obat-obatan tertentu dapat menyebabkan radang pankreas sehingga pankreas tidak berfungsi secara optimal. Faktor selanjutnya yang mempengaruhi kadar glukosa darah adalah stress.

\section{KETERBATASAN PENELITIAN}

Penelitian yang dilakukan saat ini masih memiliki keterbatasan, yaitu pada penelitian ini ada faktor-faktor yang mempengaruhi kualitas hidup yang tidak dikendalikan oleh peneliti walaupun peneliti sudah berusaha semaksimal mungkin menjaga lingkungan hewan coba tetap sama, yaitu salah satunya seperti psikologis hewan uji coba dimana faktor ini mempunyai sedikit pengaruh terhadap kondisi gula darah.

\section{KESIMPULAN}

Berdasarkan hasil penelitian dapat diambil suatu kesimpulan bahwa dalam penelitian ini rebusan daun jambu biji dapat mempengaruhi perubahan kadar glukosa darah, perubahan ini dikarenakan zat dalam daun jambu biji. Walopun demikian penelitian ini masih belum dapat dilakukan uji coba pada manusia dengan melakukan rebusan secara langsung dikarenakan perlu uji coba tingkat lanjut pada mamalia lainnya. 


\section{SARAN}

Untuk penelitian selanjutnya sebaiknya dilakukan dengan memperhatikan kembali dosis pemberian, jenis mamalia, dan lingkungan, karena percobaan pada hewan cenderung sukar dalam menjaga perilaku dan stress pada hewan akibat perubahan kondisi fisiologis maupun lingkungan yang diakibatkan oleh proses penelitian.

\section{DAFTAR PUSTAKA}

Adib, M., 2011. Pengetahuan Praktis Ragam Penyakit Mematikan yang Paling Sering Menyerang Kita. Jogjakarta: BukuBiru

Albers A. R., Krichavsky M. Z. \& Balady G. J., 2006. Stress Testing in Patients With Diabetes Mellitus Diagnostic and Prognostic Value. Circulation is availablevol pp.583-592

American Diabetes Association (ADA), 2012. Diagnosis and Classification of Diabetes Mellitus. Diabetes Care volume 35 Supplement 1 pp. 64-71.

Amalia F, 2013. Hubungan Lamanya Menderita Penyakit Diabetes Melitus Tipe 2 Terhadap Tingkat Depresi Pada Pasien Poli Penyakit Dalam RSD Dr. Soeban di Jember

Anani, S. 2012. Hubungan antara Perilaku Pengendalian Diabetes kadar Glukosa Darah pasien Rawat jalan Diabetes mellitus (Studi Kasus di RSUD Arjawinangun Kabupaten Cirebon). Medicine Journal Indonesia Vol.20 No.4:466-478
Arisman, 2011. Diabetes Mellitus : Dalam Buku Ajar Ilmu Gizi Obesitas dan

Diabetes Mellitus dan Dislipidemia. Jakarta: EGC.

Balammal., G., Muneeshwari, K. \& Khan, P. H., 2012. Recent Trends In Insulin Drug Delivery System. International Journal of Pharmaceutical Development \& Technology, 1(2), pp. $20-28$

Bhandary B, Rao S \& Sanal., 2013. The Effect of Perceived Stress and Family Functioning on People with Type 2 Diabetes Mellitus. Journal of Clinical and Diagnostic Research. Vol. 7(12), pp. 2929-2

Eom, Y.S.; Sun P.H.; Sei-Hyun K.; Sun Mee, Y.; Moon Suk, N.; Hyoung, W.L.; Young, L.K.; Sihoon, L.; Sun, K.Y.; Byung, P.L., 2011. Evaluation of Stress in Korean Patients with Diabetes Mellitus Using the Problem Areas in DiabetesKorea Questionnaire. Diabetes \& Metabolisme, Volume 35, pp. 182-187

Edward, S. 2005. Diabetes Distress Learning Center. Diabetes Master Clinician Program.

Friedman, M. M., Bowden, V. R., \& Jones, E. G., 2010. Buku Ajar Keperawatan Keluarga: Riset, Teori \& Praktik. Alih bahasa oleh Achir Yani S, et al.

Hamid. A, 2008 Asuhan Keperawatan Kesehatan Jiwa. Jakarta: Buku Kedokteran EGC

Hawari, D., 2010. Psikologi Keperawatan. Jakarta : EGC. 
.Hesti, T. 2012. Stres Pada Penyakit Terhadap Kejadian Komplikasi Hipertensi pada Pasien Hipertensi. Jurnal Kesehatan.

Jelantik, G.M.G. 2014. Hubungan Faktor Resiko Umur, Jenis Kelamin, Kegemukan dan Hipertensi dengan Kejadian Diabetes Mellitus tipe II di Wilayah Kerja Puskesmas Mataram. Jurnal Kesehatan. Denpasar. Media Bina Ilmiah. Volume 8, No 1, Februari 2014.

Kartono.K. 2006. Psikologi Abnormal dan Abnormalitas Seksual. Bandung: CV Mandar Maju.

Kekenusa j., Ratag B. T \& Wuwungan, G., 2013. Analisis Hubung antara Umur dan Riwayat Keluarga Menderita DM dengan Kejadian DM Tipe 2 pada Pasien Rawat Jalan di Poliklinik Penyakit Dalam BLU RSUP Prof. Dr. R.D. Kandou Manado.

Nasruddin, E., 2010. Psikologi Manajemen. Bandung: Pustaka Setia.

Notoatmodjo., 2005. Metodelogi Penelitian Kesehatan. Jakarta: PT. Rineka Cipta

Nugroho, S. A., 2010. Hubungan antara Tingkat Stres drngan Kadar Gula darah Pada Pasien Diabetes Melitus Di Wilayah Kerja Puskesmas Sukoharjo 1 Kabupaten Sukoharjo. pp. 4851.

Nursalam. 2008. Konsepdan Penerapan Metodologi Penelitian Ilmu Keperawatan Jakarta : Salemba Medik 